\title{
The Determinant of the COVID-19 Psychosocial Burden inWest Java Province - Indonesia
}

\author{
Hario Megatsari ${ }^{1}$, AgungDwi Laksono², Yeni Tri Herwanto ${ }^{3}$, KinantyPutri Sarweni ${ }^{3}$, NidyaEka Putri ${ }^{3}$, \\ Estiningtyas Nugraheni ${ }^{3}$, Mursyidul Ibad $^{3}$ \\ ${ }^{1}$ Lecturer, Faculty of Public Health, UniversitasAirlangga, Surabaya, Indonesia, ${ }^{2}$ Researcher, the Ministry of \\ Health of the Republic of Indonesia, Jakarta, Indonesia, ${ }^{3}$ Researcher, The Indonesian Public Health Union, \\ Makassar, Indonesia, ${ }^{4}$ Lecturer, Faculty of Health, Nadlatul Ulama University, Surabaya, Indonesia
}

\begin{abstract}
Background: West Java is one of Indonesia's provinceswith a large and dense population, making it vulnerable to quarantine or restrictions related to COVID-19. The study aims to analyze the determinants of the COVID-19 psychosocial burden in West Java Province, Indonesia.

Methods:The author collected data by online survey until it gets 653 respondents. The study reviewed psychosocial burdens by worries level. The study built the worries based on anxiety in five daily aspects: economic, religion, education, work, and social aspects. Six independent variables were involved in the analysis, including age, gender, marital status, education, employment status, and religion. In the final stage, the study carried out a multivariate test using binary logistic regression.

Results:The results found that women were 0.544 times more likely than men to experience high worries (OR 0.544; 95\% CI 0.330 - 0.896). Men are more likely than women to experience the psychosocial burden of COVID-19.Higher education has a probability of 0.405 times compared to secondary education to experience high worries (OR 0.405; 95\% CI 0.240 - 0.685). Higher education levels are a protective factor against the psychosocial burden of COVID-19 in West Java Province, Indonesia.
\end{abstract}

Conclusion:The study concluded that there are two determinants of the COVID-19 psychosocial burden in West Java, Indonesia. Both are gender and education status.

Keywords: mental health, psychosocial burden, health behavior, COVID-19.

\section{Introduction}

The COVID-19 pandemic is not going away anytime soon. There are some arguments to confirm the assumption. The most recent COVID-19 cases in the world show that the number of new cases raisedin the seven days from March29 $9^{\text {th }}$ to April $4^{\text {th }}, 2021^{1}$. Meanwhile, in Indonesia the data shown that the average

\section{Corresponding Author \\ Hario Megatsari}

Faculty of Public Health, UniversitasAirlangga,

Surabaya, Indonesia

Email: hario.megatsari@fkm.unair.ac.id number of new cases in the last 7 days was 4,000 cases ${ }^{2}$. This number indicated that the pandemic is still exist. The Indonesian government has implemented a number of strategies to break the current outbreak of COVID-19.

The Indonesian government has implemented a number of strategies to break the current outbreak of COVID-19.Some of the strategies are issuing several regulation about restriction to the mobility of people. Schools will be closed, public transportation will be suspended, and employees will be required to work from home, among other things. The primary objective of the regulation is to reduce public mobility ${ }^{3}$. 
West Java, as one of the province Indonesia, ranks second in the number of COVID 19 incidents in Indonesia ${ }^{2}$. West Java is one of Indonesia's provinceswith a large and dense population, making it vulnerable to quarantine or restrictions related to COVID-19. This situation is ironic because West Java is one of the most populated province in Indonesia, and also one of the province that very close to Jakarta as the municipality of Indonesia.The West Java Human Development Index (HDI) in 2019 reached 72.03, higher than the national average of 71.92. In the national constellation, West Java is ranked 10th out of 34 provinces in Indonesia. In the field of education, the level of Gross Enrolment Ratein West Java at the high schoollevel in 2019 was 77.82, an increasecompared to 2018 which was $75.31^{4}$.

As a consequences of the regulations and restrictions, there were several impact on all aspects of social life, including religious aspects, economic aspects, educational aspects, and social psychology aspects. This is clearly apparent from the numerous facts reported by the media about the implications of these prohibitions, including the existence of a group of people who are still required to work despite the fact that the regulation has been enforced in their territory ${ }^{5}$.The longer the community is subjected to Large Scale Social Restrictions, the more violations it commits ${ }^{6}$.

The restriction of community mobility throughout COVID-19 may cause anxiety in the form of depression and stress on society ${ }^{7,8}$.Public anxiety can result in new public health issues. WHO defines health as a good state of being in all three dimensions of human life: physical, social, and mental ${ }^{9}$. According to $\mathrm{WHO}$, anxiety is considered an unhealthy condition, so special attention must be paid to the community's situation, particularly in the current COVID-19 outbreak. Based on the background description, this study aims to analyze the determinants of the COVID-19 psychosocial burden in West Java Province, Indonesia.

\section{Methods}

\section{Data Source}

The study carried out data collection through online surveys of people who live in West Java Province, Indonesia. Data collection was carried out for eight days (June 6-13, 2020). At the end of data collection, the study found a large number of respondents were 653 respondents.

\section{Variables}

The study viewed the psychosocial burden by worries level. The worries level is built based on anxiety in five daily aspects: economic, religious, education, work, and social aspects. The study arranged each question with a choice of answers using a Likert scale. Assess the worries level by adding up the scores from the five measured aspects. Then divide it into two categories of worries level, namely low and high.

The independent variables involved in the analysis include age group, gender, marital status, education level, employment status, and religion. Age group is the respondent's acknowledgment of the last birthday that has passed. The age group consists of five categories, namely $\leq 19,20-29,30-39,40-49$, and $\geq 50$. Gender consists of twotypes, namely male and female. Meanwhile, marital status consists of two categories, namely single/divorced/widowed and married. Education level is the respondent's recognition of the level of education that has been passed. Education level consists of two categories, namely secondary and under, and higher. Employment status is the respondent's recognition of the work that is currently being done. Employment status consists of two groups, namely unemployed and employed. Religion consists of two categories, namely Muslim and non-Muslim.

\section{Data Analysis}

At the initial stage, a bivariate test was carried out with Chi-Square to test the relationship between the dependent and independent variables. In the final step, the study carried out a multivariate test using 
binary logistic regression to determine the COVID-19 psychosocial burden in West Java, Indonesia. The author employed all statistical analyzes using IBM Statistic SPSS 21 software.

\section{Ethical Approval}

This study is part of a study on the psychosocial burden of the community during the COVID-19 pandemic period in Indonesia, which has received ethical approval from the national ethics commission (No: RK.05/KEPK/STIK/V/2020). The study deleted all the respondents' identities from the dataset. Respondents have provided written approval for their involvement in the research.

\section{Results and Discussion}

Table 1 shows the descriptive statistics of respondent characteristics. It can be seen that the 20-29 age group dominates all categories of worries level. Based on gender, all types of worries levels are dominated by female respondents. Meanwhile, based on marital status, all classes of worries level are dominated by married respondents.

Table1. Descriptive Statistics of Respondent Characteristics $(n=653)$

\begin{tabular}{|c|c|c|c|c|c|}
\hline \multirow{3}{*}{ Variables } & \multicolumn{4}{|c|}{ Worries Level } & \multirow{3}{*}{$\mathrm{p}$-value } \\
\hline & \multicolumn{2}{|c|}{ Low } & \multicolumn{2}{|c|}{ High } & \\
\hline & $\mathrm{n}$ & $\%$ & $\mathrm{n}$ & $\%$ & \\
\hline Age groups & & & & & $* * * 0.000$ \\
\hline$\leq 19$ & 5 & 4.3 & 25 & 4.7 & \\
\hline $20-29$ & 34 & 29.1 & 254 & 47.4 & \\
\hline $30-39$ & 24 & 20.5 & 129 & 24.1 & \\
\hline $40-49$ & 23 & 19.7 & 77 & 14.4 & \\
\hline$\geq 50$ & 31 & 26.5 & 51 & 9.5 & \\
\hline Gender & & & & & $* 0.035$ \\
\hline Male & 25 & 21.4 & 167 & 31.2 & \\
\hline Female & 92 & 78.6 & 369 & 68.8 & \\
\hline Marital status & & & & & $* 0.016$ \\
\hline Single/Divorced/Widowed & 40 & 34.2 & 249 & 46.5 & \\
\hline Married & 77 & 65.8 & 287 & 53.5 & \\
\hline Education level & & & & & $* * * 0.000$ \\
\hline Secondary and under & 31 & 26.5 & 282 & 52.6 & \\
\hline Higher & 86 & 73.5 & 254 & 47.4 & \\
\hline Employment status & & & & & 0.725 \\
\hline Unemployed & 21 & 17.9 & 89 & 16.6 & \\
\hline Employed & 96 & 82.1 & 447 & 83.4 & \\
\hline Religion & & & & & 0.084 \\
\hline Moslem & 106 & 90.6 & 508 & 94.8 & \\
\hline Non-moslem & 11 & 9.4 & 28 & 5.2 & \\
\hline
\end{tabular}


Note: ${ }^{*} \mathrm{p}<0.05 ;{ }^{* *} \mathrm{p}<0.01 ;{ }^{* * *} \mathrm{p}<0.001$.

Based on the education level, respondents who experienced low worries were dominated by higher education. Otherwise, respondents who experience high worries are dominated by respondents with secondary education. Based on employment status, the two categories of worries level are dominated by employed respondents. Finally, based on religion, all types of worries level are dominated by respondents with the Muslim.

Table 2 displays information on the result of binary logistic regression of COVID-19 psychosocial burden in West Java Province, Indonesia. The study tested four independent variables at this final stage. The four variables are age group, gender, marital status, and education level.
Based on the results of the analysis shown in Table 2, it can be seen that two variables have proven significant as determinants of the psychosocial COVID-19 in West Java Province, Indonesia. First, gender. Females are 0.544 times more likely than males to experience high worries (OR 0.544; 95\% CI 0.330 - 0.896). This analysis indicates that in West Java Province, males are more likely than females to experience the psychosocial burden of COVID-19.

In the Indonesian context, the male is responsible for earning a living for all household members of a household ${ }^{10}$. The situation with strict social restrictions during the COVID-19 pandemic made men as husbands bear a double burden. The burden related to COVID-19 includes the responsibility to make a living, which is also getting more difficult ${ }^{11,12}$. The situation can trigger a heavier psychosocial burden on the male in West Java Province ${ }^{13}$.

Table 2. The result of binary logistic regression of the COVID-19 psychosocial in West Java Province, Indonesia, $2020(\mathrm{n}=653)$

\begin{tabular}{|c|c|c|c|c|}
\hline \multirow{2}{*}{ Variables } & \multicolumn{3}{|c|}{ The High Worries } \\
\cline { 2 - 5 } & \multirow{2}{*}{ P-value } & OR & \multicolumn{2}{|c|}{$95 \%$ CI } \\
\cline { 2 - 5 } & & & Lower Bound & Upper Bound \\
\hline Age: $\leq 19$ & - & - & - & - \\
\hline Age: $20-29$ & 0.232 & 1.913 & 0.660 & 5.539 \\
\hline Age: $30-39$ & 0.337 & 1.792 & 0.544 & 5.903 \\
\hline Age: $40-49$ & 0.613 & 1.378 & 0.398 & 4.768 \\
\hline Age: $\geq 50$ & 0.546 & 0.686 & 0.202 & 2.329 \\
\hline Gender: Male & - & - & - & - \\
\hline Gender: Female & $* 0.017$ & 0.544 & 0.330 & 0.896 \\
\hline Marital: Single/Divorced/Widowed & - & - & - & - \\
\hline Marital: Married & 0.625 & 0.876 & 0.515 & 1.490 \\
\hline Education: Secondary and under & - & - & - & - \\
\hline Education: Higher & $* * 0.001$ & 0.405 & 0.240 & 0.685 \\
\hline
\end{tabular}

Note: ${ }^{*} \mathrm{p}<0.05 ;{ }^{* *} \mathrm{p}<0.01 ;{ }^{* * *} \mathrm{p}<0.001$ 
Second, education level. Higher education has a probability of 0.405 times compared to secondary education to experience high worries (OR 0.405; 95\% CI $0.240-0.685)$. This information suggests that higher education is a protective factor against the psychosocial burden of COVID-19 in West Java Province, Indonesia.

A better education level makes it easier for a person to understand the situation at hand and the risks involved ${ }^{8,14}$. These findings are in line with several other studies conducted with the same theme in several countries ${ }^{15-17}$. Several previous studies have also found that a better education level has a good impact on performance output in the health sector ${ }^{18,19}$. On the other hand, low education levels are a barrier to achieving higher quality performance in the health sector ${ }^{20,21}$.

\section{Conclusions}

Based on the analysis results, the study concluded that there are two determinants of the COVID-19 psychosocial burden in West Java, Indonesia. The two variables are gender and education status.

Acknowledgments: The author would like to thank all the Indonesian Public Health Union and IKA Airlangga Surabaya for allowing online survey data on psychosocial.

Conflict of Interest: The authors declare no conflict of interest, financial or otherwise.

\section{References}

1. Association AL. Coronavirus Data [Internet]. 2021 [cited 2021 Apr 4]. Available from: https://www. worldometers.info/coronavirus/

2. COVID-19 STP. Peta Sebaran Kasus COVID-19 Indonesia [Internet]. 2021 [cited 2021 Apr 4]. Available from: https://covid19.go.id/peta-sebaran

3. Task Force for the Acceleration of Handling COVID-19. COVID-19 Health Handling Protocol (Protokol Kesehatan Penanganan COVID-19). Indonesia; 2020 p. 1-10.

4. Province B-S of JB. Jawa Barat Province in Figures 2020 [Internet]. Bandung; 2020. Available from: https://jabar.bps.go.id/ publication/ download.html?nrbvfeve $=\quad$ Y2ZhYjlhNDAw
Medico-legal Update, October-December 2021, Vol.21, No. 4175 $\mathrm{Y} 2 \mathrm{Yz}$ MDRmODAwM TgyYTVm \&xzmn= aHR0cHM6Ly9q YWJhci5icHMu Z28ua WQvcHVib GljYXR pb24v MjAyMC8w NC8yNy9j ZmFiOWE0MD BjZjMwNGY4MD AxODJhNWYvc HJvdmluc2ktam vF3YS1iYXJhd C1kYW xhbS1 hbmdrYS0yMDIw Lmh0bWw\%3D \& twoadfnoarfeauf $=$ MjAyMS0w $\mathrm{NCO} w$ NCAwNjow MjoxMw\%3D\%3D

5. Laksono AD, Ibad M, Herwanto YT, Sarweni KP, Geno RAP, Nugraheni E. Evaluation of the Implementation of Large Scale Social Restrictions in East Java, Indonesia (Evaluasi Pelaksanaan Pembatasan Sosial Berskala Besar di Jawa Timur, Indonesia). Surabaya; 2020.

6. Ibad M, Laksono AD, Herwanto YT, Sarweni KP, Geno RAP, Nugraheni E. East Java Needs "Public Health" Police (Jawa Timur Perlu Polisi "Kesehatan Masyarakat"). Surabaya; 2020.

7. Bohlken J, Schömig F, Lemke MR, Pumberger M, Riedel-Heller SG. COVID-19 Pandemic: Stress Experience of Healthcare Workers: A Short Current Review. Psychiatr Prax. 2020;47(4):190-7.

8. Megatsari H, Laksono AD, Ibad M, Herwanto YT, Sarweni KP, Geno RAP, et al. The community psychosocial burden during the COVID-19 pandemic in Indonesia. Heliyon. 2020;6(10):Article number $\mathrm{e} 05136$.

9. World Health Organization. Preamble to the Constitution of WHO. New York, Geneva; 1946.

10. Megatsari H, Laksono AD, Herwanto YT, Sarweni KP, Geno RAP, Nugraheni E, et al. Does husband/ partner matter in reduce women's risk of worries?: Study of psychosocial burden of covid-19 in indonesia. Indian $\mathrm{J}$ Forensic Med Toxicol. 2021;15(1):1101-6.

11. Megatsari H, Laksono AD, Ibad M, Herwanto YT, Sarweni KP, Geno RAP, et al. Predictors of Psychosocial Burden among Workers During the COVID-19 Pandemic Period in Indonesia. MedicoLegal Updat. 2021;21(1):292-7.

12. Kurniawati D, Rochmah TN, Laksono AD. The Policy of Large-Scale Social Restriction (LSSR): Prevention Effort of COVID-19 and Community Compliance in Indonesia. Medico-Legal Updat. 2020;20(4):159-63.

13. Laksono $\mathrm{AD}$, Megatsari $\mathrm{H}$, Herwanto $\mathrm{YT}$, Sarweni KP, Geno RAP, Nugraheni E, et al. The Gender Disparities in the Psychosocial Burden of 
COVID-19 in East Java Province, Indonesia. Int J Innov Creat Chang. 2020;14(2):1172-84.

14. Laksono AD, Wulandari RD, Ibad M, Herwanto YT, Sarweni KP, Geno RAP, et al. Predictors of Healthy Lifestyle in The COVID-19 Pandemic Period in East Java, Indonesia. J Crit Rev. 2020;7(18):1515-21.

15. Mukhtar S, Rana W. COVID-19 and individuals with mental illness in psychiatric facilities. Psychiatry Res. 2020;289:Article number 113075.

16. Choudhari R. COVID 19 pandemic: Mental health challenges of internal migrant workers of India. Asian J Psychiatr. 2020;54:Article number 102254.

17. Petzold MB, Plag J, Ströhle A. Dealing with psychological distress by healthcare professionals during the COVID-19 pandemia. Nervenarzt. 2020;91(5):417-21.
18. Laksono AD, Wulandari RD, Kusrini I, Ibad M. The effects of mother's education on achieving exclusive breastfeeding in Indonesia. BMC Public Health. 2021;21(1):14.

19. Kusrini I, Fuada N, Supadmi S, Laksono AD. Education as Predictor of Low Birth Weight among Female Worker in Indonesia. Medico-Legal Updat. 2021;21(1):360-5.

20. Rohmah N, Yusuf A, Hargono R, Laksono AD, Masruroh, Ibrahim I, et al. Determinants of teenage pregnancy in Indonesia. Indian J Forensic Med Toxicol. 2020;14(3):2080-5.

21. Laksono AD, Wulandari RD. The Barrier to Maternity Care in Rural Indonesia. J Public Heal From Theory to Pract. 2020; Online First. 